\title{
Calculation of the Tyre Curing Mould Cavity Shape Using FEM
}

Jan Kledrowetz, Jakub Javořík, Rohitha Keerthiwansa, Pavel Nekoksa

Faculty of Technology, Tomas Bata University in Zlin. Vavrečkova 275, 76272 Zlín. Czech Republic. E-mail: kledrowetz@ft.utb.cz

This paper describes a modelling methodology that predicts a contour of a pneumatic tyre in the curing mould. Tyre contour is designed to be in the equilibrium shape. Such shape is described by a system of complex mathematical equations that has to be solved numerically. In this new approach a standard FEM software is employed to gain the shape without the need of dealing with these equations manually. The quality of the proposal of FEM approach was assessed by comparing the meridian to a verified solution for several tyre constructions and sizes. Selected results are presented to show the accuracy of the FE modelling procedure. Nowadays, most of the produced tyres are of a radial construction. Therefore, this paper deals only with radial tyres.

Keywords: Equilibrium shape, Tyre contour, Tyre mould, FEM, MSC Marc/Mentat

\section{Acknowledgement}

This work and the project is realized with the financial support of the internal grant of TBU in Zlin No. IGA/FT/2017/002 funded from the resources of specific university research.

\section{References}

[1] ZHU, B., et al. (2017). Practical Design of an Energy Harvester Considering Wheel Rotation for Powering Intelligent Tire Systems. Journal of Electronic Materials. Vol. 46, No. 4, pp 2483-2493.

[2] KENNEDY, R.H. (2001). Prediction of Tire Shape Change During Post Cure Inflation. Tire Science and Technology. Vol. 29, No. 4, pp. 198-215.

[3] PURDY, J.F. (1963). Mathematics Underlying the Design of Pneumatic Tires. Hiney Printing Company, Akron, Ohio: 1963.

[4] GENT, A.N. (2005). Walter, J.D. The Pneumatic Tire. Washinghton, D.C.: NHTSA, 2005.

[5] BIDERMAN, V. L., BUKHIN, B. L. et al. (1974). Mechanics of Pneumatic Tires I (Russian), Moscow: 1974.

[6] KOUTNÝ, F. (2007). Geometry and Mechanics of Pneumatic Tires. Zlín: UTB in Zlín, 2007.

[7] NAKAJIMA, Y., KAMEGAWA, T., Abe, A. (1996). Theory of Optimum Tire Contour and Its Application. Tire Science and Technology. Vol. 24, No. 3, pp. 184-203.

[8] CORNISTEIN, R., ARECHAGA T. (2016). Parametric Contour Design. Tire Technology International. Annual Showcase, pp. 42-45.

[9] LI, X., WEI, Y., FENG, Q. et al. (2017). Mechanical behavior of nylon 66 tyre cord under monotonic and cyclic extension: Experiments and constitutive modelling. Fibers and Polymers. Vol.18, No.3, 542-548

[10] SMETANKA, L. et al. (2015) Homogenization of Fibers Reinforced Composite Materials for Simulation Analysis. Manufacturing Technology. Vol. 15, No. 5, pp. 914-920.

[11] YOU, J. et al. (2016). Contact Analysis of Silicone Rubber Rectangular Ring in the Automatic Tighten Assembly. Manufacturing Technology. Vol. 16, No. 3, pp. 648-653.

[12] ŽMINDÁK, M., PELAGIC, Z., SOUKUP (2015), J. Analysis of Fiber Orientation Influence to Dynamic Properties of Composite Structures. Manufacturing Technology. Vol. 15, No. 3, pp. 490-494. 